\title{
NOTIONS, NUANCES AND CONNOTATIONS OF IDIOMS WITH NAMES OF FRUIT AND VEGETABLES IN ALBANIAN
}

\author{
HARALLAMB MICONI'
}

"Eqrem Cabej" University, Gjirokaster, Albania

\begin{abstract}
The purpose of this study is to show that the lexical field with names of fruit and vegetables in Albanian is of special interest for the field of phraseology as well. Thanks to fruit and vegetables and the names of this field, man can create a language of reason and express their attitude to reality. In this study we mainly focused on the nuances and connotations of these idioms as lexical content elements that make the meaning expressed by an idiom distinct from the meaning expressed by an one-word equivalent. Our conclusion is that the observed nuances are negative, such as the idea of futility, evil, rush, etc., while as far as connotations are concerned, most of them are negative, such as the connotation of disregard, irony, derision, etc., but there is also a positive connotation, such as the connotation of admiration. Regarding the nature of the properties and actions that idioms express, $85 \%$ of them characterize man, that is, they have an anthropocentric nature.
\end{abstract}

\section{UDC CLASSIFICATION \& KEYWORDS}

81-37 Lexical field - Notion - Nuance - Connotation
Negativity INTRODUCTION

The semantic sphere of language encodes all available knowledge about the history, culture, habits and ways of a particular nation. This information is expressed through language means, mostly words and idioms. This collection and reflection of cultural data is first realized in words, because they are immediately related to extra-linguistic phenomena, but this feature is obviously manifested in the totality of idioms as well, that is, the linguistic elements that carry cultural national experience.

Before describing the constituent elements of the lexical content of the idioms with names of fruit and vegetables, one needs to clarify the term idiom. An idiom is a set expression whose meaning can not be deduced from a literal definition of its parts and, instead, refers to a non-literal or figurative meaning which is only known through conventional use. Idioms' components are characterized by their inseparability and should not be considered as isolated, but as a complex and lexicalized unit that can build synonymic relations with other simple or complex units. Such are even the idioms with names of fruit and vegetables we study. The whole number of names of fruit and vegetables in Albanian language are 50 , but those that are used as components in Albanian idioms are mainly nut, pear, thorny bush, fig, beans, garlic, pumpkin, cabbage, leeks, apple, grape, wheat, etc. The number of idioms with the names of this lexical field is 140. Some of them are: si fiku me arrën, të thyen arrën në dorë, thyej arra kot, ka në dorë edhe gurin edhe arrën, s'bëjnë dardhat në shënëndre, nuk i ka hyrë ferrë në këmbë, si iriqi në ferrë, e ka ferrë në sy, e mori ferra uratën, i vuri ferrën diçkaje, gjethe fiku, kur të hipë gomari në majë të fikut, i nxjerr gështenjat nga zjarri me duart e të

' miconisllambi@yahoo.gr tjerëve, i bëri paratë rrush e kumbulla, limon i shtrydhur, si kokërr molle, s'ke ku te hedhësh mollën, shkoi (u vra) si qeni në rrush, hiqnin të zitë e ullirit, tund degën e ullirit, s'e ha atë kokërr ulliri, shtie me bathë, siç duken bathët, e zunë me domate dikë, nuk më ftohen fasulet, e ka grurë me dikë, mbolli thekër e i doli grurë dikujt, ngul qepë e shkul hudhra, grin lakër, i dolën lakrat lakrorit, është hapur si vaji në lakra, e ha preshin nga bishti, është rritur me bishtra preshi, mos i shit kastraveca bostanxhiut! This variety of idioms is explained by the importance of fruit and vegetables in feeding people during the centuries. Man gets from fruit and vegetables, from their appearance and functions, an amazing idiomatic creativity.

\section{Notions}

Here it should be pointed out that despite their evidently important expressive function, idioms are in the first place nominative. Just like words, idioms serve to formulate concepts and thus play a significant role in the process of conceptualization (Mejri, 2003). Due to the indirect (figurative) type of nomination, they create a specific model of the world which is called idiomatic. Like most idioms, idioms with names of fruit and vegetables in Albanian are "equivalent" to words (Thomai, 1981). They express the same notions as their equivalent words and can be used along with them in the Albanian language lexicon, that is, they establish synonymic relations with them.

We will call prevalent notions those which are represented by a greater number of idioms, in our case by the idioms with names of fruit and vegetables. The most prevalent notions in Albanian are the notion of poverty with 5 idioms, such as ishin bathët te numëruara (lit. The beans were counted), rronte me një shoshë lakra (lit. He/she lived on a bowl of greens), është rritur me bishtra preshi (lit. He/she has grown up on ends of leeks), ferra e nisi, ferra e grisi dikë (lit. He/she started with thorny bushes and these thorny bushes tore them), nuk i ngjitej (nuk e kapte) ferra askund (lit. No thorny bush could stick to him), the notion good luck with 5 idioms, such as i ka rënë pjergulla në fik (lit. A wine arbour has fallen off on his/her fig-tree), si pjergulla në fik të bardhë (lit. As a wine arbour on a white fig-tree), i shkon puna grurë (lit. His/her work functions as wheat), mbolli thekër e i doli grurë dikujt (lit. He/she planted ray and it came up as wheat), i ka rënë shiu në lakra (lit. The rain has fallen on his greens), the notion of speaking with 4 idioms, such as grin lakër (sallatë) (lit. He/she grinds some cabbage), s'i mban goja arra dikujt (lit. His/her mouth doesn't keep nuts), thyej arra kot (lit. He/she cracks nuts in vain), kakaris si pula pa grurë (lit. He/she clucks as a chicken without wheat), the notion of revelation with 3 idioms, such as do t'i dalin dardhat dikujt (lit. His/her pears will come out), i dolën (iu zbuluan) lakrat lakrorit (lit. The cabbage pie's greens came out), e zuri (e kapi, e gjeti) ndër lakra (lit. He/she was caught among the greens), the notion of concern with 3 idioms, such as $u$ bë lule kungulli (lit. He/she became a pumpkin flower), i hynë ferrat (lit. Thorny bushes got into him/her), jam si në ferra (lit. I am as among thorny bushes), the notion 
of similarity with 3 idioms, such as si rrushi e koshi (lit. As

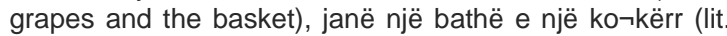
They are a bean and a grain), pinë në një kungull (lit. They drink water in the same pumpkin), the notion of impossibility with 3 idioms, such as kërkon dardha në dimër (lit. He/she asks for pears in winter), kërkon dardha nga boriga (lit. $\mathrm{He} / \mathrm{she}$ asks for pears out of the black pine), kërkon rrush në dimër (lit. He/she asks for pears in winter), the notion of ability with 2 idioms, such as i ha arrat dikujt (lit. He/she eats someone's nuts), të thyen arrën në dorë (lit. He/she cracks the nut in your hand), the notion of failure with 3 idioms, such as i doli dardhë diçka (lit. Something came up as a pear-tree for him/her), mbjell misër e korr tallë (lit. He/she plants corn and harvests oat-grass), mbolli bostan e i dolën kastraveca (lit. $\mathrm{He} / \mathrm{she}$ planted watermelons but they came up as cucumbers), the notion of rush with 3 idioms, such as i peshon arrat pa i shkundur (lit. He/she weighs nuts without giving nut-trees a shake), shkund manin në prill (lit. He/she gives the mulberry-tree a shake in April), e shkund arrën në korrik) (lit. He/she gives the nut-tree a shake in July), the notion of boasting with 2 idioms, such as zbrit nga fiku! (lit. Come down from the fig-tree), $u$ bë (u rrit) kungulli e mori (e zuri) gardhin (lit. The pumpkin grew ripe and and took the fence), the notion never with 3 idioms, such as kur të bëjë qarri arra (lit. When the Turkish oak makes nuts), kur të hipë gomari (derri) në fik (lit. When the donkey gets on the fig-tree), kur të bëjë larushku rrush (lit. When the wild wine makes grapes), the notion of abandonment with 2 idioms, such as i vuri ferrën diçkaje (lit. He/she put some thorny bush to sth), ia mbylli derën me ferra dikujt (lit. $\mathrm{He}$ /she closed their door by putting thorny bush), the notion of suffering with 2 idioms, such as nuk i ka hyrë ferrë në këmbë (lit. No thorny bush has gone into his/her foot), hiqnin të zitë e ullirit (lit. He/she got out the black wasted water from olives), the notion of using someone with 2 idioms, such as e qëroi si hudhër dikë (lit. He/she peeled him as a garlic), limon i shtrydhur (lit. A squashed lemon), the notion of destruction with 2 idioms, such as e mori ferra uratën (lit. The wish has been taken by the thorny bush), e bëri lakër diçka apo dikë (lit. He/she grinded it or him as a cabbage), the notion of spreading words with 2 idioms, such as e mori ferra fjalën (lit. The word has been taken away by the thorny bush), vajti te molla e kuqe (lit. The word went to the red apple-tree), the notion of spending with 2 idioms, such as i bëri paratë rrush e kumbulla (lit. He/she gave their money for grapes and plums), e ha grurin që në arë (lit. He/she eats their wheat in the field).

Most of the idioms that express the same notion are synonyms among them. There are even cases where all idioms that express the same notion are synonyms, such as the 5 cases of idioms with the notion of good luck: i ka rënë pjergulla në fik (lit. A wine arbour has fallen off on his/her fig-tree), si pjergulla në fik të bardhë (lit. As a wine arbour on a white fig-tree), i shkon puna grurë (lit. His/her work functions as wheat), mbolli thekër e i doli grurë dikujt (lit. He/she planted ray and it came up as wheat), i ka rënë shiu në lakra (lit. The rain has fallen on his greens). All of them mean the same thing "he/she is very lucky".

The notions expressed by the names of fruit and vegetables are divided into three groups:

- Negative notions, such as frivolity, dirtiness, loquacity, theft, rush, difficulties, immaturity, quarrel, poverty, loneliness, hatred, suffering, abandonment, boasting, spending, death ingratitude, futility, uselessness, failure, etc. whose number is about five times more than the positive notions.

- Positive notions, such as skill, good luck, etc.
- Neutral notions, such as matching, possibility, search, speaking, spreading, experience, distinction, never, explanation, etc. Even though some notions are neutral, the idioms which express them, turn out to be negative in their semantic idiomatic complexity (as we will see it below), such as the notion of speaking in thyej arra kot for to say useless things/ to talk in vain, grin laker (sallatë) for to say too much and in vain, kakaris si pula pa grurë for to talk without thinking and in vain.

We should also mention some notions which, although not so prevalent as the notions above, are almost extreme in assessing man, that is, they are very negative or very positive. Such are the notion of frivolity, e.g. arrë fyçkë for a frivolous man/ someone who is empty-headed, the notion of rush, e.g. e shkund arrën në korrik for someone who has no patience at all, the notion of dispute, e.g. e shpunë dardhë for people who argue with each-other harshly, the notion of theft, e.g. të thyen arrën në dorë for someone who is very skillful, the notion of hatred, e.g. e ka ferrë në sy dikë for someone we hate very much, the notion of fraud, e.g. tund degën e ullirit for someone who tries to show others that he/she is an ardent defendant of peace in order to hide his/her warlike intentions, the notion of ingratitude, e.g. të ha shalqirin e të rreh me lëkura for someone who is ungrateful, or the notion of health, e.g. si kokërr molle for someone who is in very good health, the notion of persistence, e.g. sikur qeni qepën të hajë for something that should be done necessarily, the notion of friendship, e.g. mollë e pandarë for people who are close friends, the notion of peace, e.g. dega e ullirit for the symbol of peace.

Most of the notions, hence most of the idioms, with names of fruit and vegetables are used to show people's actions and qualities. This is because phraseology is anthropocentric by its nature - semantics of most units revolves around man or they are used to show his activities, attitudes and traits of character (Čermák, 1998). Man tries to modulate reality as commensurable with himself, tries, so to speak, to humanize the objects of the outer world. That is why man is described as arrë fyçkë (lit. An empty nut) for a frivolous man/ someone who is empty-headed, as limon i shtrydhur (lit. A squashed lemon) for someone who has been used by others and then abandoned as useless. $85 \%$ of idioms with names of fruit and vegetables are used to characterize man, such as mos i shit kastraveca bostanxhiut!, mbolli bostan e i dolën kastraveca, trangul1 (kungull) pa fara, e kapën (e zunë, e gjetën) me presh në dorë, ia nxori lakrat në shesh, e zunë me domate dikë and only $15 \%$ of them are not used to characterize man, such as lëng ndër lakra for something with no importance, bulmet hudhrash for a frivolous affair, ishin bathët te numëruara for a family's difficult economic situation.

\section{Nuances}

If the reason for the existence of idioms is denomination, the reason for their creation is the differentiation, assessment and expressiveness that the user wants to convey to the listener and the reader. Thus, as far as nuance is concerned, some idioms have a different semantic nuance from their synonymous words (Desporte\&MartinBerthet, 2001). Among the nuances prevailing in the group of idioms with names of fruit and vegetables is the idea of futility with 15 cases and which accompanies the notion of speaking, e.g. thyen arra kot (lit. He/she cracks nuts in vain) for he/she speaks in vain, grin lakër (sallatë) (lit. He/she grinds some cabbag) for he/she speaks in vain, the notion of spending, e.g. i bëri paratë rush e kumbulla (lit. He/she gave their money for grapes and plums) for he/she spent all their money in vain, the notion of hope, e.g. sillet kot rreth 
dardhës dikush (lit. He/she goes round the pear-tree in vain) for he/she hopes in vain, the notion of involvement, e.g. hyri nëpër lakra (lit. He/she went into the greens) for someone who is involved in vain in the others' affairs, the notion of work, e.g. hedh kripë në ferra (lit. He/she cast salt to the thorny-bushes) for someone who does a useless work, the idea of evil with 4 cases and which accompanies the notion of revelation, e.g. e zuri ndër lakra (lit. He/she was caught among the greens) for they caught him/her in wrongdoing, do t'i dalin dardhat dikujt (lit. His/her pears will come out) for a secret evil thing that will be revealed, the idea of rush with 3 cases, e.g. i peshon arrat pa i shkundur (lit. He/she weighs nuts without giving nut-trees a shake) for someone who makes decisions without thinking, the idea of trick with 1 case, e.g. të thyen arrën në dorë (lit. He/she cracks the nut in your hand) for someone who is very skillful, the idea of contempt with 1 case, e.g. e zunë me domate dikë (lit. $\mathrm{He}$ /she was thrown tomatoes) for someone who is expelled with contempt, the idea of using people with 1 case, e.g. nxjerr gështenjat nga zjarri me duart e të tjerëve (lit. He/she gets the chestnuts out of the fire by the others' hands) for someone who carries out a job by using others, which are negative.

\section{Connotations}

Some idioms with names of fruit and vegetables in Albanian have a marked affective connotation and a high expressiveness in comparison with their one-word synonyms. They express the speaker's attitude to what is mentioned whereas synonymous words can be neutral. Idioms are basically used to assess situations, states and actions or the participants in them, as positive or negative, smart or funny (Vlachopoulos,2007), whereas, thanks to their figurativeness, they increase the expressiveness of the text. Affective connotation gives the words and idioms the ability to express the speaker's attitude to what is said, how they (the speakers) assess it (with love, hugs, admiration, contempt, derision, disdain, etc.). By a general division, we can distinguish two kinds of connotations: affective positive connotation and affective negative connotation (Thomai, 2006).

Among the main negative connotations expressed through the idioms with names of fruit and vegetables is the connotation of disregard with 40 cases, e.g. kungull pa fara (lit. Pumpkin without grains) for someone who is not clever, bathë ka ngrënë e bathë mollois, mish me presh e presh me mish, s'i mban goja arra dikujt, si rrushi e koshi, humbi si fasulja në vegsh, the connotation of irony with 30 cases, e.g. kur të bëjë larushku rrush (lit. When the wild wine makes grapes) for never, tund degën e ullirit, bulmet hudhrash, e kam (jemi) lakra (presh) në kopsht, mos i shit kastraveca bostanxhiut!, kur të hipë gomari në fik, the connotation of disdain with 15 cases, e.g. arrë fyçkë (lit. An empty nut) for a frivolous man/ someone who is empty-headed, pinë në një kungull, të thyen arrën në dorë and the connotation of derision with 5 cases, e.g. ra nga fiku (lit. He/she fell off the fig-tree) for someone has lost their position at work, shtie me bathë, është tre mel e dy grurë.

The most common positive connotation expressed by idioms with names of fruit and vegetables is the connotation of admiration, e.g. si fiku me arrën (lit. As the fig and the nut) for people who match and have good relations, e ka grurë me dikë, të thyen arrën në dorë.

Speaking in a general way, we can say that fruit and vegetables constitute a common food which is related to the concrete, daily things, to what is less processed - the earth's products, which explains their general value of contempt (Amerlynck, 2006). Those fruit and vegetables that are

viewed negatively by man form more idioms. But, even those that are positive can form idioms with a negative value, such as with nut when they are based on the nuts' secondary qualities and functions, e.g. shtagë arrash (lit. Nut pole) for a tall and very thin person, s'i ndahet arra në dorë dikujt (lit. Nuts are always in his hands) for someone who is very dirty, and not on their nutritional value, or such as with wheat when it does not constitute the basic word of the idiomatic unit, e.g. kakaris si pula pa grurë, ra si pula në grurë. The positive connotation is thus used only in idioms with wheat and mainly with apple, e.g. e ka grurë me dikë, i shkon puna grurë, si kokërr molle, mollë e pandarë.

Nuances and connotations are important because they determine the meaning and the distinction between idioms and their equivalent words, such as u ngopa me bathë = I have been annoyed, but because of something being repeated. In both cases we have the notion of annoyance, but in the case of the idiom we have the nuance of repetition which is the reason for the annoyance. In most cases we have an overlapping of the same value among the constituent elements of the lexical content of an idiom. For example, in i bëri paratë rrush e kumbulla we have the negative values of spending and futility, or in e zunë me domate dikë we have the negative values of opposition and contempt. But there are also cases when the notion is neutral, such as that of speaking or revelation, whereas the nuance is negative. In these cases, the nuance makes idiomatic meaning differentiated from the meaning of the synonymous word, such as in thyej arra kot, grin lakër (sallatë) where the negative idea of futility determines the negative value of these idioms' meaning.

But not all idioms can have a nuance or a connotation that distinguish them from their equivalent words. In this case, the differentiating role towards the equivalent words is assumed by the intensity and expressivity which are present values even in idioms with a nuance or a connotation, because they are more general and they constitute a good reason for the existence of a lot of idioms without a connotation or a special nuance, such as in i ka rënë pjergulla në fik, hiqnin të zitë e ullirit, sic duken bathët, e kapën me presh në dorë, i bëri paratë rrush e kumbulla.

\section{Conclusion}

The most prevailing notions among idioms with names of fruit and vegetables are the negative ones.

The main negative notions are the notions of poverty, suffering, anxiety, failure, abandonment and using someone. The main positive notions are the notion of good luck and the notion of ability. The main neutral notions are the notions of matching, speaking, revelation, experience, distinction, etc.

As idioms are created for their non-denotative value, what is of special importance is their nuance and connotation, because they determine the difference in meaning between a lot of idioms and their equivalent words with which they express the same notion.

The nuances expressed by the idioms we study are negative, such as the ideas of futility, evil, rush, trick, using someone, etc.

Most widespread connotations are the negative one, such as the connotations of disregard, irony, disdain and derision, but we also find the positive connotation of admiration.

In most cases, Albanian language relates idioms with names of fruit and vegetables to negative actions and qualities, and mostly man's. The reason for the prevalence of negativity in notions as well as in nuances and connotations is justified 
by man's tendency to see and to point out the other persons' faults and their desire to laugh at these faults.

\section{REFERENCES}

1. Amerlynck, J. (2006). Phraséologie potagère: les noms de légumes dans les expressions françaises contemporaines. Peeters Louvain-la-Neuve.

2. Čermák, F. (1998): Somatic idioms revisited. In: Eismann, W. (ed.): Europhras 95 - Europäische Phraseologie im Vergleich: Gemeinsames Erbe und kulturelle Vielfalt.

3. Desporte, A. \& Martin-Berthet, F. (2001). Noms d'animaux et expressions en français et en espagnol.In: Langages, 35e année, $\mathrm{n}^{\circ} 143$.

4. Dictionary of Linguistics and Phonetics. Blackwell Publishing 2008 (sixth edition).

5. Fjalori i gjuhës së sotme shqipe (1980). Tiranë.

6. Fjalori i shqipes së sotme. (1984). Tiranë.

7. Fliatouras, A. (2001). Greek-Albanian phraseological isoglosses based on members and organs of human body. In: ALBANOHELLENICA No 2.

8. Longman Dictionary of Language Teaching and Applied Linguistics. Pearson Education Limited 2002 (Third Edition).

9. Mejri, S. (2003). La stéréotypie du corps dans la phraséologie: approche contrastive. In: Burger, H./Häcki Buhofer, A./Gréciano, G. (Hrsg.).

10. Thomai, J. (1981). Çështje të frazeologjisë së gjuhës shqipe. Tiranë.

11. Thomai, J. (1999). Fjalor frazeologjik i gjuhës shqipe. Tiranë.

12. Thomai, J. (2006). Leksikologjia e gjuhës shqipe. Botimet Toena, Tiranë.

13. Vlachopoulos, S. (2007) Dictionary of Modern Greek Idioms.

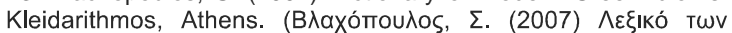

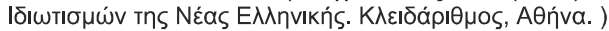

